\title{
PENGEMBANGAN MODUL FISIKA BERBASIS SAINS TEKNOLOGI MASYARAKAT (STM) UNTUK MENINGKATKAN MOTIVASI BELAJAR DAN KEMAMPUAN BERPIKIR KRITIS SISWA SMA
}

\author{
Sujiyani Kassiavera ${ }^{1}$, Widha Sunarno ${ }^{2}$, A Suparmi ${ }^{3}$ \\ ${ }^{1}$ Program Studi Magister Pendidikan Sains FKIP Universitas Sebelas Maret \\ Surakarta, 57126, Indonesia \\ sujiyanikassiavera@student.uns.ac.id \\ ${ }^{2}$ Program Studi Magister Pendidikan Sains FKIP Universitas Sebelas Maret \\ Surakarta, 57126, Indonesia \\ widhasunarno@staff.uns.ac.id \\ ${ }^{3}$ Program Studi Magister Pendidikan Sains FKIP Universitas Sebelas Maret \\ Surakarta, 57126, Indonesia \\ soeparmi@staff.uns.ac.id
}

\begin{abstract}
Abstrak
Pembelajaran yang digunakan masih bersifat konvensional sehingga masih kurangnya pemahaman siswa dalam memahami konsep pembelajaran fisika terkait aplikasinya pada kehidupan sehari-hari. Rata-rata hasil ujian nasional di sekolah menengah atas tahun 2013/2014 adalah 68,76 ini menunjukkan permasalahan dalam proses pembelajaran fisika, sehingga diperlukan alat bantu pembelajaran berbentuk modul. Tujuan dari penelitian ini adalah untuk:1) mendeskripsikan karakteristik modul fisika berbasis STM untuk meningkatkan motivasi belajar dan kemampuan berpikir kritis siswa SMA pada materi suhu dan kalor, 2) mengembangkan modul fisika berbasis STM yang layak untuk meningkatkan motivasi belajar dan kemampuan berpikir kritis siswa SMA pada materi suhu dan kalor,3)meningkatkan motivasi belajar siswa SMA pada materi suhu dan kalor, 4) meningkatkan kemampuan berpikir kritis siswa SMA pada materi suhu dan kalor, dan 5) meningkatkan hasil belajar siswa SMA pada materi suhu dan kalor. Penelitian ini merupakan penelitian Research and Developmentyang mengadaptasi model 4-D dari Thiagarajan(1974) yang meliputi tahapdefine, design, developdan disseminate. Instrumen yang digunakan adalah angket, lembar observasi dan tes. Uji lapangan operasional menggunakan one group pretestposttest design. Analisis data yang digunakan dalam penelitian dalam tahap define adalah analisis deskriptif, pada tahap design menggunakan analisis $\mathrm{KD}$, tahap develope menggunakan analisis kuantitatif deskriptif dengan cara mengkonversi data menjadi kategori skala 4 untuk hasil validasi modul, hasil penilaian sikap dan hasil penilaian keterampilan sedangkan penilaian motivasi belajar dan kemampuan berpikir kritis siswa dianalisis menggunakan $n$-gain ternormalisasi. Tahap disseminate menggunakan analisis deskriptif dari hasil penilaian modul dalam kategori skala 4. Berdasarkan analisis data diperoleh hasil penelitian dan pengembangan sebagai berikut:1) modul yang dikembangkan berbasis STM, dengan tahapan: invitasi, pembentukan konsep, aplikasi konsep, pemantapan konsep dan evaluasi; 2) modul memenuhi kategori sangat baik dari hasil validasi oleh validator materi, media, bahasa, review dan peer review. Aspek kelayakan isi \& penyajian, kelayakan bahasa dan kelayakan kegrafikan; 3) modul efektif meningkatkan motivasi belajar siswa. Hasil perhitungan $\mathrm{N}$-gain yaitu 0,5 dari pretest dan posstest yang dikategorikan sedang; 4)modul efektif meningkatkan kemampuan berpikir kritis siswa, hasil perhitungan $N$-gain yaitu 0,39 yang dikategorikan sedang. Hasil perhitungan $N$-gain yaitu 0,5 dari pretest dan posstest yang dikategorikan sedang; 5) pembelajaran menggunakan modul berbasis STM dapat meningkatkan hasil belajar siswa terlihat bahwa 93\% siswa mencapai KKM.
\end{abstract}

Kata Kunci : Modul, Sains Teknologi Masyarakat (STM), Motivasi Belajar, Kemampuan Berpikir Kritis, Hasil Belajar. 


\section{Pendahuluan}

Pembelajaran sains merupakan pembelajaran yang dapat membuat siswa membangun sendiri kemampuannya dengan cara mengeksplorasi seluruh pikiran dalam mempelajari dan menemukan sendiri konsep belajarnya. Putra (2013), menyatakan bahwa produk yang dihasilkan oleh siswa ketika melaksanakan pembelajaran sains yaitu meningkatnya penguasaan cara berpikir siswa yang berupa fakta, konsep, prinsip, hukum, dan teori mengenai alam dan sifatnya yang dihasilkan dari keingintahuanketika menjalani pembelajaran sains. Tidak semua materi dapat disampaikan atau cocok menggunakan metode ceramah. Hal tersebut yang menjadi salah satu faktor kurang maksimalnya prestasi siswa dalam pembelajaran. Poedjiadi (2010: 98) bahwa "Pembelajaran formal maupun nonfomal diharapkan dapat memberi pengalaman bagi pesertanya melaluilearning to know, learning to do, learning to be and learning to live together".

Dalam urutan pembelajaran sangat penting untuk ditentukan dalam langkah kegiatan pembelajaran. Pembelajaran dapat dirancang untuk memberikan kesempatan seluas-luasnya kepada peserta didik untuk belajar secara aktif dan kreatif dalam menemukan sebuah fakta ilmiah atau konsep. Fakta ilmiah atau konsep ini dan Salah satu bentuk bahan ajar yang dapat dibuat yaitu modul pembelajaran. MenurutWinkel (2009) modul pengajaran merupakan seperangkat bahan pelajaran yang memuat bahan dan petunjuk pembelajaran meliputi tujuan dan petunjuk pembelajaran, bahan bacaan siswa, lembar kerja siswa, dan alat evaluasi pembelajaran. Dengan mengacu tujuan utama untuk meningkatkan kemampuan siswa maka diharapkan pembuatan bahan ajar juga mampu meningkatkan kemampuan berpikir siswa. Pada dasarnya "Modul merupakan bahan ajar cetak yang dirancang untuk dapat dipelajari secara mandiri oleh peserta pembelajaran. Modul disebut juga modul untuk belajar mandiri karena di dalamnya telah dilengkapi petunjuk untuk belajar sendiri (Depdiknas, 2008). Modul merupakan salah satu bentuk bahan ajar yang dikemas secara utuh dan sistematis, didalamnya memuat seperangkat pengalaman belajar yang terencana dan didesain untuk membantu peserta didik menguasai tujuan belajar yang spesifik. Modul minimal memuat tujuan pembelajaran, materi/substansi belajar dan evaluasi (Depdiknas, 2008: 4). Modul yang akan dirancang mampu menarik motivasi belajar dan meningkatkan kemampuan berpikir kritis siswa.

Pembelajaran berbasis STM merupakan pembelajaran yang mampu mengaitkan antara sains dan teknologi serta manfaatnya bagi masyarakat Poedjiadi (2010: 98). Oleh karena itu, pembelajaran berbasis STM yang baik dilengkapi dengan ilustrasi gambar yang menarik, ilustrasi konsep fisika dalam kehidupan sehari-hari siswa dan percobaan fisika yang melibatkan aktivitas siswa.

Sardiman (2008: 75) mendefinisikan motivasi sebagai keseluruhan daya penggerak diri siswa yang menimbulkan kegiatan belajar, yang menjamin kelangsungan dari kegiatan belajar yang memberikan arah pada kegiatan belajar, sehingga tujuan yang dikehendaki oleh subjek belajar itu dapat tercapai. Motivasi adalah perubahan dalam diri atau pribadi seseorang yang ditandai dengan yang ditimbulkan perasaan dan reaksi untuk mencapai tujuan.

Pengembangan kemampuan berpikir kritis dalam proses pembelajaran juga dapat menjadi salah satu cara untuk meningkatkan prestasi belajar siswa. Hal ini sesuai yang diungkapkan oleh Fisher (2010) bahwa keterkaitan berpikir kritis dalam proses pembelajaran adalah perlunya mempersiapkan siswa agar menjadi pemecah masalah yang tangguh, pembuat keputusan yang matang, dan orang yang tak pernah berhenti belajar.Sadia (2014: 40) menyatakan dengan melihat karakteristik model pembelajaran STM yang disesuaikan 
dengan karakteristik pengembangan modul dapat memberi solusi untuk meningkatkan kemampuan berpikir kritis siswa.

Berdasarkan analisis kebutuhan yang dilakukan di SMA Insan Cendekia AlMujtaba Sukoharjo melalui analisis kebutuhan siswa didapatkan data pemahaman siswa terhadap proses belajar mengajar yaitu $72,8 \%$ dan masih terdapat siswa yang mengaku mengalami kesulitan belajar karena keterbatasan sumber belajarnya. Maka dari itu diperlukan solusi alternatif untuk mengatasi masalah belajar anak-anak tersebut, salah satunya melalui pembuatan modul. Dalam analisis tersebut juga didapatkan data bahwa $81,5 \%$ siswa menyatakan butuh bahan ajar yang juga dapat membantu termotivasisnya siswa sehingga mampu mengasah tingkat kemampuan. Sedangkan hasil analisis kebutuhan guru menyebutkan bahwa hanya $58,3 \%$ bahan ajar yang sesuai dengan pembelajaran fisika. Guru juga masih mengalami kesulitan dalam mengembangkan perangkat pembelajaran yang efektif, inovatif, kreatif dan menyenangkan dalam mengimplementasikan pendidikan sesuai dengan kurikulum KTSP yang ideal, sehingga diperoleh data sebesar $89 \%$ guru membutuhkan bahan ajar yang mampu meningkatkan kualitas siswa menjadi lebih baik.

Materi yang dipilih dalam penelitian ini adalah materi suhu dan kalor yang antara lain membahas suhu dan termometer, pemuaian dan kalor.Pemilihan materi suhu dan kalor ini didasarkan pada hasil nilai ujian nasional tahun pelajaran 2013/2014. Daya serap siswa pada materi suhu dan kalor untuk lingkup nasional sebesar $68,76 \%$, lingkup provinsi Jawa Tengah sebesar 74,20\%, lingkup kabupaten sebesar 66,42 dan 58,06 untuk lingkup sekolah. Persentase daya serap ini lebih rendah daripada daya serap materi lainnya. Sehingga dapat dikatakan bahwa siswa masih mengalami kesulitan dalam memahami materi suhu dan kalor.

Penelitian ini bertujuan untuk:1) mendeskripsikan karakteristik modul fisika berbasis STM, 2) mengembangkan modul fisika berbasis STM yang layak untuk meningkatkan motivasi belajar dan kemampuan berpikir kritis siswa SMA pada materi suhu dan kalor, 3) meningkatkan motivasi belajar siswa SMA pada materi suhu dan kalor, 4) meningkatkan kemampuan berpikir kritis siswa SMA pada materi suhu dan kalor, dan 5) meningkatkan hasil belajar siswa SMA pada materi suhu dan kalor.

\section{Metode Penelitian}

Metode penelitian yang digunakan yaitu research and development atau penelitian dan pengembangan. Model yang digunakan sebagai dasar untuk mengembangkan modul fisika berbasis Sains Teknologi Masyarakat (STM) ini merupakan hasil adaptasi model 4-D yang dikemukakan oleh Thiagarajan(1974) yang meliputi proses define, design, develop, dan disseminate.

Desain penelitian yang digunakan adalah one group pretest and posttest, sehingga penelitian hanya melibatkan sekelompok subjek yang diberi pre-test sebelum dikenai perlakuan, dan post-test setelah dikenai perlakuan untuk diketahui hasil akibat perlakuan tersebut.

Metode pengumpulan data yang digunakan pada penelitian ini yaitu dengan teknik observasi, angket dan tes. Teknik analisis data yang digunakan adalah analisis kebutuhan, analisis kelayakan modul, analisis motivasi, analisis berpikir kritis dan analisis hasil belajar.

Data yang diperoleh pada penelitian pengembangan modul berbasis STM pada materi suhu dan kalor untuk siswa SMA/MA kelas $\mathrm{X}$ adalah data analisis kebutuhan siswa, data analisis kebutuhan guru, data validasi modul oleh validator ahli (materi, bahasa dan media), guru fisika dan teman sejawat, data nilai peningkatan motivasi belajar, data nilai peningkatan kemampuan berpikir kritis, data nilai sikap, pengetahuan dan keterampilan, dan data penilaian produk oleh siswa, guru fisika, 
dan teman sejawat. Data yang diperoleh dari analisis kebutuhan siswa dan analisis kebutuhan gurukemudian ditabulasi dan dikonversi menjadi bentuk persentase. Hasil validasi modul, nilai sikap, nilai keterampilan dan hasil penilaian produk dianalisis dan dikonversi menjadi skala 4 kemudian dilakukan analisis deskriptif terhadap hasilnya. Hasil penilaian pengetahuan dianalisis dengan membuat rata-rata nilai kemudian dibandingkan dengan kriteria ketuntasan minimal mata pelajaran fisika.

\section{Hasil dan Pembahasan Penelitian}

Model yang digunakan sebagai dasar untuk mengembangkan modul fisika berbasis STM ini merupakan hasil adapatasi model 4-D (four-D model) yang dkemukakan oleh Thiagarajan(1974)dalam yang meliputi proses define, design, develop, dan disseminate yang menunjukkan hasil sebagai berikut :

\section{A. Tahap Define}

Tahap ini merupakan tahapan untuk mengidentifikasi masalah-masalah yang ada dalam proses pembelajaran dan menjadi dasar untuk merancang produk berupa modul yang dibuat. Pada tahapan ini dilakukan analisis kebutuhan siswa dan analisis kebutuhan guru.

Penelitian dilakukan terhadap 27 siswa yang berasal dari kelas X SMA Insan Cendekia Al-Mujtaba Sukoharjo. Data yang dihasilkan antara lain Secara keseluruhan, hasil analisis kebutuhan tersebut menggambarkan bahwa siswa tersebut membutuhkan pengembangan bahan dan sumber belajar dari luar. Padahal menurut Daryanto (2013:23) menyebutkan bahwa pemanfaatan sumber belajar berupa media pembelajaran penting agar membuat komunikasi dalam kegiatan belajar semakin efektif dan efisien. Atas dasar tersebut maka besar kemungkinan pengembangan modul pembelajaran dapat mengatasi permasalahan tersebut.Terbukti $81,5 \%$ kalau siswa membutuhkan bahan ajar. Hal tersebut membuat siswa mengalami kesulitan dalam belajar dari luar. Hal ini diperkuat oleh hasil penelitian Kiong et al (2011) bahwa penggunaan modul dapat menjadi alternatif dalam pemecahan masalah belajar siswa.

Analisis kebutuhan guru dilakukan menggunakan bantuan angket kebutuhan guru dan dilakukan terhadap 2 guru fisika diSMA Insan Cendekia Al-Mujtaba Sukoharjo. Hasil analisis antara lain menunjukkan bahwa bahan ajar yang sesuai dengan pembelajaran fisika hanya $58,3 \%$. Atas pertimbangan analisis kebutuhan guru tersebut, maka dikembangkan modul pembelajaran fisika berbasis STM dalam usaha meningkatkan kualitas pembelajaran. Pertimbangan tersebut dikuatkan oleh hasil penelitian Bakar et al (2006) yang menyebutkan bahwa penggunaan STS atau STM dapat menerapkan konsep-konsep ilmiah yang berkaitan dengan sains teknologi masyarakat sehingga timbul sikap yang lebih positif dan kreativitas yang lebih baik.

Materi yang dipilih dalam penelitian ini adalah materi suhu dan kalor. Hal ini berdasarkan hasil daya serap penguasaan materi soal ujian nasional SMA/MA yang dikeluarkan oleh Balai Penilaian Pendidikan Badan Penelitian dan Pengembangan Kementrian Pendidikan dan Kebudayaan yang tergolong masih rendah di SMA Insan Cendekia Al-Mujtaba Sukoharjo $(53,45 \%)$ dan perlu adanya perbaikan. Berdasarkan Permendikbud RI no.59 Tahun 2014, tentang pilihan model pembelajaran yang sesuai dengan karakteristik kompetensi mata pelajaran fisika menyebutkan bahwa kompetensi dasar menerapkan faktor-faktor terjadinya suhu dan kalor dalam kehidupan seharihari pada kelas X sangat cocok diterapkan dengan pembelajaran berbasis STM. Atas pertimbangan tersebut, layak jika dikembangkan modul pembelajaran berbasis STM pada materi suhu dan kalor. 


\section{B. Tahap Design}

Dalam tahap design ini maka dibuat desain modul yang sesuai dengan sintaks STM yang telah diintegrasikan ke dalam komponen modul. Sintaks invitasi diintegrasikan ke dalam rubrik 'Fenomena', sintaks pembentukan konsep diintegrasikan ke dalam rubrik 'Lembar Kerja Siswa (LKS)', sintakaplikasi konsep diintegrasikan ke dalam rubrik 'Penerapan', sintaks pembentukan konsep diintegrasikan ke dalam rubrik 'Uraian Materi', dan sintaks evaluasi diintegrasikan ke dalam rubrik 'Tes Formatif'.

Seluruh desain pembelajaran STM yang disusun diatas kemudian dikemas kedalam tiga kegiatan belajar (KB) dan dilengkapi dengan rubrik 'Renungkan' 'Tahukah Kamu', 'Sang Penemu', daftar pustaka dan glosarium. Desain modul yang sudah jadi selanjutnya diisi dengan materi suhu dan kalor. Modul yang sudah jadi kemudian di validasi dan di revisi sesuai dalam tahap pengembangan (develop) dalam proses penelitian selanjutnya.

\section{Tahap Develop}

Tahapan Developini diawali dengan validasi draft 1 modul fisika berbasis STM yang dilakukan oleh validator ahli, guru fisika dan teman sejawat yang selanjutnya direvisi dan ujicobakan ke kelompok kecil dan kelompok besar.

\section{Hasil Validasi Modul}

Validasi dilakukan oleh dua validator ahli, dua guru fisika dan dua teman sejawat. Validasi dilakukan menggunakan lembar validasi yang mengadaptasi lembar validasi buku teks pelajaran dari BSNP tahun 2014. Validasi modul menitikberatkan pada komponen kelayakan isi dan penyajian, bahasa, pembelajaran berbasis STM, dan kelayakan kegrafikan. Validator ahli materi memvalidasi modul yang telah dibuat dengan menilai komponen penyajian materi yang terdiri dari komponen kelayakan isi, komponen penyajian, komponen kebahasaan, dan komponen pembelajaran berbasis STM, sedangkan komponen yang dinilai dari segi media dalam modul adalah komponen kegrafikan. Validator ahli media yang menilai tentang kelayakan kegrafikan modul dan ahli bahasa yang menilai tentang kebahasaan di dalam modul. Terdapat juga dua guru fisika dan dua teman sejawatjuga menilai komponen materi yang terdiri dari komponen kelayakan isi, komponen penyajian, komponen kebahasaan dan komponen pembelajaran STM.

Diagram batanghasil validasi modul pembelajaran berbasis Sains Teknologi Masyarakat (STM) yang dikembangkan diperlihatkan dalam Gambar 1.

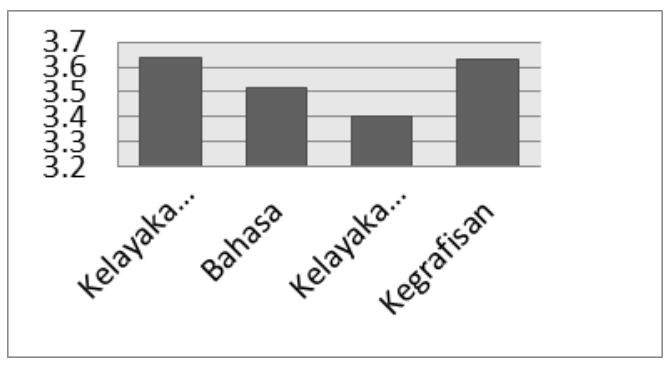

Gambar 1. Hasil Validasi Modul

Hasil validasi yang ditunjukkan Gambar 1 memperlihatkan bahwa modul pembelajaran berbasis STMyang dikembangkan mendapatkan hasil dengan kategori sangat baik hal ini terlihat bahwa materi yang disajikan lengkap, fakta dan konsep yang disajikan akurat, materi yang disajikan sesuai dengan kurikulum, SK dan KD. Nilai aspek kelayakan isi dan penyajian yang diperoleh sebesar 3,64 . Uji validasi oleh ahli media diperoleh hasil dengan kategori sangat baik hal ini terlihat dari penyajian keseluruhan ilustrasi serasi, kemudahan ilustrasi mudah dipahami, dan ketepatan desain cover dan warna pada modul sesuai. Nilai aspek kelayakan kegrafikan yang diperoleh sebesar 3,63. Uji validasi oleh ahli bahasa diperoleh hasil dengan kategori sangat baik hal ini terlihat dari kalimat yang digunakan dalam modul tidak menimbulkan makna ganda, kalimatnya mudah dipahami, bahasa yang digunakan komunikatif, dan bahasa yang digunakan menarik perhatian siswa. Presentase aspek kelayakan bahasa sebesar 3,52. Modul ini juga mendapatkan respon baik dari siswa hal ini terlihat dari siswa 
yang antusias dalam mempelajari modul, kemampuan modul untuk meningkatkan minat baca siswa, dan penggunaan bahasa yang mudah dipahami oleh siswa. Hasil keterbacaan siswa diperoleh nilai sebesar 3,5. Kelayakan juga didukung oleh hasil disseminate yang mengkategorikan modul tergolong sangat baik hal ini terlihat dari guru yang memberi komentar bahwa modul yang dikembangkan sesuai dengan kaidah bahasa dan kemampuan kognisi siswa SMA. Hasil keterbacaan guru diperoleh nilai sebesar 3,33.

\section{Revisi I}

Setelah validasi dilakukan, draf I kemudian direvisi berdasarkan saran/ masukan dari validator seperti ditampilkan dalam Tabel 1.

Tabel. 1 Hasil Revisi Modul dari Validator

\begin{tabular}{|c|c|}
\hline Sebelum revisi & Setelah revisi \\
\hline $\begin{array}{l}\text { Peta konsep harus saling } \\
\text { berhubungan dengan yg } \\
\text { lain dan dan diberi } \\
\text { keterangan } \\
\text { penghubung }\end{array}$ & $\begin{array}{l}\text { Peta konsep telah } \\
\text { diperbaiki dengan } \\
\text { menghubungkan } \\
\text { antar konsep dan } \\
\text { keterangan antar } \\
\text { penghubung }\end{array}$ \\
\hline $\begin{array}{l}\text { Masih banyak kesalahan, } \\
\text { baca EYD terbaru per } \\
\text { tanggal } 26 \text { November } \\
2015\end{array}$ & $\begin{array}{l}\text { Kesalahan-kesalahn } \\
\text { telah diperbaiki dan } \\
\text { telah sesuai dengan } \\
\text { EYD terbaru }\end{array}$ \\
\hline $\begin{array}{l}\text { Warna sampul tidak } \\
\text { disenergikan dengan } \\
\text { warna tulisan sampul }\end{array}$ & $\begin{array}{l}\text { Warna sampul telah } \\
\text { sinergi dengan } \\
\text { warna tulisan pada } \\
\text { sampul }\end{array}$ \\
\hline $\begin{array}{l}\text { Lay-out sebaiknya diganti } \\
\text { yang lebih sederhana dan } \\
\text { warnanya di sinergikan } \\
\text { dengan sampul depan }\end{array}$ & $\begin{array}{l}\text { Lay-Out sudah } \\
\text { diperbaiki sehingga } \\
\text { terlihat sederhana }\end{array}$ \\
\hline
\end{tabular}

Secara umum perbaikan dilakukan dari segi materi, visualisasi dan kebahasaan. Perbaikan dari segi materi diantaranya memperbaiki peta konsep. Perbaikan peta konsep berdasarkan teori dari Dahar (1989) menjelaskan bahwa langkah-lankah pembuatan peta konsep salah satunya yaitu menghubungkan konsep yang berkaitan dengan garis-garis penghubung dan memberi kata penghubung pada setiap garis penghubung itu. Perbaikan dari segi visualisasi diantaranya lay-out, dan sampul, perbaikan ini telah dilakukan berdasarkan teori dari Sukiman (2012). Perbaikan dari kebahasaan diantaranya perbaikan redaksi penulisan berdasarkan Depdiknas (2015) pedomanejaan bahasa Indonesia per tangal 26 November 2015. Setelah draf I direvisi dihasilkan draf II berdasarkan masukan dan saran dari validator. Draf II selanjutnya diujicobakan terbatas kepada 12 siswa kelas $X$ SMA Insan Cendekia Al-Mujtaba Sukoharjo yang terdiri dari siswa dengan kemampuan tinggi, sedang dan rendah yang diambil dari gabungan kelas XI IPA 1 putra dan XI IPA 2 putri.

\section{Uji Coba Kecil (Uji Terbatas)}

Tahapan uji coba terbatas ini dilakukan setelah mendapatkan produk yaitu modul cetak pembelajaran fisika berbasis Sains Teknologi Masyarakat (STM) pada materi suhu dan kalor yang sudah divalidasi oleh validator. Data menunjukkan bahwa hasil uji coba terbatas diperoleh nilai rata-rata seluruhnya 89,9. Apabila skor tersebut dikonversi ke dalam interval 4 maka diperoleh nilai penilaian 3,33 sehingga modul ini termasuk dalam kriteria 'sangat baik'. Nilai tersebut mengartikan bahwa menurut modul pembelajaran fisika berbasis STM pada materi suhu dan kalor yang dikembangkan sangat baik dalam segi isi/ materi, sangat baik dalam segi kebahasaannya dan sangat baik juga dalam segi gambar dan penyajiannya.

\section{Revisi II}

Hasil dari ujicoba terbatas juga berupa saran dan masukan dari siswa yang diperbaiki oleh peneliti, diantaranya perbaikan terhadap hasil cetakan yang kurang jelasdan warna lay-out yang belum sinergi didalam modul. Disusun kembali menjadi draft modul III yang diimplementasikan pada uji coba lapangan di gabungan kelas X1 putra dan X2 putri SMA Insan Cendekia Al-Mujtaba Sukoharjo sejumlah 29 siswa. 
5. Uji Coba Besar (Uji Lapangan)

Data yang didapatkan dalam ujicoba lapangan dengan penerapan pembelajaran menggunakan modul pembelajaran fisika berbasis STM pada materi suhu dan kalor ini meliputi data hasil penilaian motivasi belajar, kemampuan berpikir kritis, kemampuan pengetahuan, sikap, dan keterampilan. Selain hal tersebut, siswa juga diminta untuk melakukan penilaian terkait penggunaan modul pembelajaran STM dalam mendampingi pemahaman materi tentang suhu dan kalor.

\section{a. Penilaian Motivasi Belajar Siswa}

Penilaian motivasi belajar siswa dilakukan pada 29 siswa kelas X1 putra dan X2 putri SMA Insan Cendekia Al-Mujtaba Sukoharjo dengan menggunakan pre dan post test dari angket motivasi belajar berdasarkan penggunaan modul pembelajaran berbasis STM pada penyampaian materi suhu dan kalor.

Aspek penilaian motivasi belajar siswa terdiri dari 3 indikator, meliputiindikator: (1) keinginan, mengalami peningkatan nilai ketercapaian dari 74,1 menjadi 90,4. Indikator (2) percaya diri, mengalami peningkatan nilai ketercapaian dari 74,4 menjadi 87,9. Indikator (3) hasil optimal, mengalami peningkatan nilai ketercapaian dari 65,1 menjadi 78 hingga diperoleh nilai rata-rata sebesar 71,2. Seluruh data nilai motivasi belajar siswa ditampilkan dalam Gambar 2.

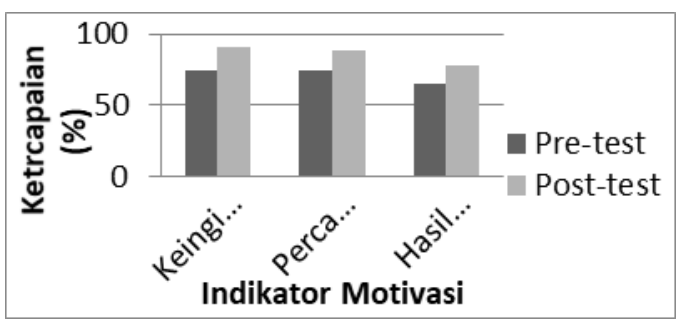

Gambar 2. Grafik Peningkatan Motivasi Belajar Siswa

Berdasarkan Gambar 2 dapat disimpulkan bahwa pembelajaran menggunakan modul fisika berbasis STM pada materi suhu dan kalor efektif digunakan sebagai bahan ajar baru di sekolah, keefektifan modul didasarkan pada peningkatan motivasi belajar siswa. Motivasi belajar yang diteliti meliputi keinginan, percaya diri dan hasil maksimal. Peningkatan setiap aspek motivasi belajar dilihat dari pretest dan posttest yang dihitung menggunakan gain score ternormalisasi yang mendapatkan skor 0,5 dengan kategori sedang. Motivasi belajar yang memiliki $\mathrm{N}$-Gain paling tinggi yaitu aspek keinginan, kedua percaya diri dan yang ketiga hasil optimal. Aspek keinginan ini berada pada langkah invitasi.

Hasil penelitian tersebut ternyata senada dengan hasil penelitian Perdana(2016) yang menyatakan bahwa Pengembangan modul elektronik mampu meningkatkan motivasi belajar siswa yaitu dilihat dari peningkatan nilai rata-rata motivasi belajar awal siswa sebelum dilakukan proses kegiatan pembelajaran dan setelah menggunakan modul.

\section{b. Penilaian Kemampuan Berpikir Kritis}

Data kemampuan berpikir kritis yang diperoleh dari uji coba besar adalah data Pretest dan Posttest . Pembuatan soal berpikir kritis merujuk pada aspek berpikir kritis dari Facione (2011). Penilaian kemampuan berpikir kritis dilakukan sebelum kegiatan pembelajaran dengan diberi soal pretest terlebih dahulu.

Hasil pretest disajikan pada tabel 4.13 menunjukkan bahwa kemampuan berpikir kritis awal siswa hampir semua siswa rendah. Sanjaya (2008: 94) mengungkapkan penyebab rendahnya kemampuan berpikir siswa adalah pada saat pembelajaran, guru tidak berusaha mengajak siswa untuk berpikir. Guru menganggap bagi siswa menguasai materi pelajaran lebih penting dibandingkan dengan mengembangkan kemampuan berpikir. 


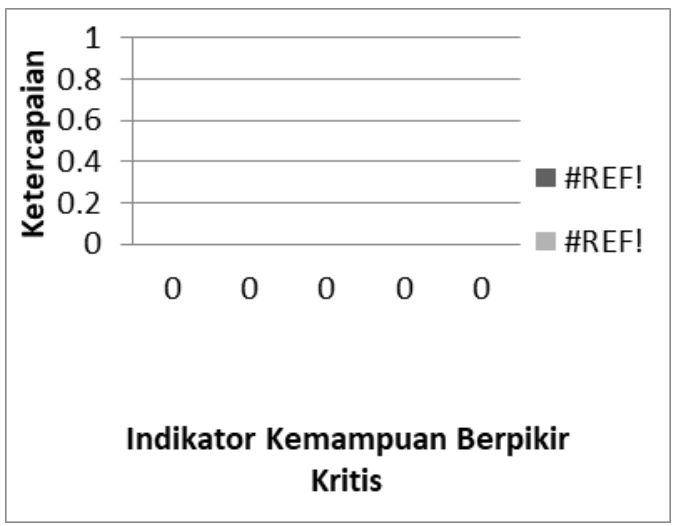

Gambar 2. Grafik Peningkatan Kemampuan Berpikir Kritis Siswa

Berdasarkan hasil uji prasyarat menunjukkan data berdistribusi normal dan homogen. Dari Gambar 2 dapat disimpulkan bahwa pembelajaran menggunakan modul fisika berbasis STM pada materi suhu dan kalor efektif digunakan sebagai bahan ajar baru di sekolah, keefektifan modul didasarkan pada peningkatan kemampuan berpikir kritis siswa. Kemampuan berpikir kritis yang diteliti meliputi interpretation, anallisys, inference, explanation dan evaluation. Peningkatan setiap aspek kemampuan berpikir kritis dilihat dari pretest dan posttest yang dihitung menggunakan gain score ternormalisasi yang mendapatkan skor 0,39 dengan kategori sedang. Kemampuan berpikir kritis yang memiliki $N$-Gain paling tinggi yaitu aspek explanation, kedua anallisys, ketiga inference, keempat evaluation dan yang kelima interpretation. Aspek Explanation ini berada pada langkah pemantapan konsep.

\section{c. Hasil Belajar Aspek Kognitif}

Penilaian aspek Kognitif siswa yang diukur dalam penelitian ini yaitu nilai LKS dan Tes Formatif untuk masing-masing kegiatan belajar $(\mathrm{KB})$ yang terdapat dalam modul.

Hasil penelitian menjelaskan bahwa Kegiatan Belajar (KB).1 tentang suhu dan termometer mempunyai nilai rata-rata 73 , KB.2 tentang pemuaian dengan nilai ratarata 79 dan KB.3 tentang kalor dengan nilai rata-rata 86. Secara keseluruhan hasil belajar menggunakan modul berbasis STM ini dinyatakan berhasil karena nilai rata-rata siswa80 sudah melebihi angka kriteria ketuntasan minimal yaitu 75. Hasil penelitian ini senada dengan penelitian Perdana (2016) bahwa dengan penggunaan modul elektronik fisika menunjukkan hasil belajar yang diperoleh bahwa $87 \%$ siswa pada kelas sampel dan kelas kontrol mencapai KKM.

\section{d. Hasil Belajar Aspek Afektif}

Penilaian komponen sikap ilmiah dilakukan selama pelaksanaan pembelajaran menggunakan modul berbasis STM yang pengamatannya dibantu oleh observer I dan observer II dalam penilaiannya. Aspek yang dinilai adalah rasa ingin tahu, tanggung jawab, ketelitian, kerjasama dan jujur.

Hasil penelitian menjelaskan bahwa Kegiatan Belajar (KB).1 tentang suhu dan Termometer mempunyai nilai rata-rata 75,95 , KB.2 tentang pemuaian dengan nilai rata-rata 80,15 dan KB.3 tentang kalor dengan nilai rata-rata 86,15. Secara keseluruhan hasil belajar menggunakan modul berbasis STM ini dinyatakan berhasil karena nilai rata-rata siswa $(80,75)$ sudah melebihi angka kriteria ketuntasan minimal yaitu 75. Dengan demikian dari hasil penilaian memperlihatkan bahwa sikap afektif siswa dalam pembelajaran menggunakan modul berbasis STM ini mulai membudaya. Sikap yang dimaksud berarti adalah rasa ingin tahu yang mulai berkembang baik, tanggung jawab yang terlihat berkembang baik, ketelitian belajar yang mulai berkembang baik, kerjasama dalam pembelajaran yang mulai berkembang baik dan jujur yang ditunjukkan dalam proses pembelajaran juga mulai berkembang baik menuju pembiasaan yang membudaya.

\section{e. Hasil Belajar Aspek Psikomotor}

Penilaian komponen sikap psikomotor dilakukan setiap pelaksanaan pembelajaran yaitu pada saat melakukan percobaan dengan menggunakan modul 
berbasis STM yang pengamatannya dibantu oleh observer I dan observer II dalam penilaiannya. Aspek yang dinilai adalah menyiapkan alat dan bahan, melakukan percobaan dan merapikan alat dan bahan.

Hasil penelitian menjelaskan bahwa KB.1 tentang suhu dan termometer mempunyai nilai rata-rata 80,2 , KB.2 tentang pemuaian dengan nilai rata-rata 79 danKB.3 tentang kalor dengan nilai ratarata 86. Secara keseluruhan hasil belajar menggunakan modul berbasis STM ini dinyatakan berhasil karena nilai rata-rata siswa $(84,2)$ sudah melebihi angka kriteria ketuntasan minimal yaitu 75 .

Hasil ini juga menjawab tantangan hasil penelitian Rohmadi(2011) bahwa pendekatan CEP bervisi SETS atau STM dapat meningkatkan nilai kognitif siswa, nilai afektif, nilai psikomotor, keaktifan siswa, motivasi dan minat siswa dalam belajar.

\section{f. Penilaian Produk oleh Siswa}

Modul pembelajaran berbasis STM ini setelah pembelajaran selesai dilakukan penilaian oleh siswa mengenai komponen isi/ materi, bahasa dan tampilan/ gambar dalam bentuk angket penilaian produk yang terdiri dari 27 butir deskriptor. Komponen isi/ materi terdiri dari 11 butir, komponen kebahasaan 3 butir, dan komponen tampilan/ gambar terdiri dari 13 butir.

Hasil penilaian 29 siswa di kelas X1 putra dan X2 putri SMAN Insan cendekia Al-Mujtaba Sukoharjo tersebut mengkategorikan modul pembelajaran berbasis STM ini dalam kriteria 'Sangat Baik'. Rincian penilaian modul oleh siswa tersebut yaitu 3,62 pada komponen isi/ materi yang tersaji dalam butir angket nomor 1-11, kemudian nilai 3,41 untuk skor kebahasaan yang tersaji dalam butir angket nomor 12-14 dan nilai 3,42 untuk skor penilaian tampilan/gambar pada butir angket nomor 15-27. Nilai rata-rata keseluruhan modul adalah 3,5 (sangat baik) yang mengartikan bahwa modul pembelajaran fisika berbasis STM mempunyai kualitas yang sangat baik dari segi materi, bahasa dan tampilan/ gambarnya. Penilaian tersebut mengartikan bahwa modul sangat baik dipakai dalam pembelajaran sehingga dapat menjadi alternatif pendekatan dalam pemecahan permasalahan siswa seperti yang diungkapkan dalam penelitian Kiong et al (2011).

6. Penyempurnaan (Revisi III)

Hasil uji lapangan dan penilaian produk dari siswa menunjukkan bahwa isi/ materi sudah baik, bahasa di dalam modul juga sudah baik dan tampilan/gambar sudah sangat baik sehingga tahap selanjutnya adalah menyempurnakan modul dari saran beberapa siswa dalam uji lapangan utama. Saran tambahan dalam revisi III ini hanya sedikit, diantaranya penambahan penerapan materi. Perbaikan yang lebih sedikit daripada revisi sebelumnya, hal ini menunjukkan bahwa modul yang dikembangkan sudah lebih baik dari sebelumnya dan siap untuk disebarkan ke sekolah-sekolah lain.

\section{Tahap Disseminate}

Pada tahap penyebaran, modul fisika berbasis STM pada materi suhu dan kalor ini disebarkan di 5 sekolah di kota Surakarta. Penyebaran dilakukan di SMA Islam, SMA Majelis Tafsir Al-Quran (MTA), SMA Muhammadiyah 6, SMA Warga dan SMA Muhammadiyah 1. Setelah diberikan modul fisika berbasis STM beserta RPP pada materi suhu dan kalor ini kemudian guru-guru tersebut melakukan penilaian yang disajikan dalam angket respon dan keterbacaan modul yang terdiri dari 5 pertanyaan.

Hasil penilaian memperlihatkan secara rinci data penilaian produk oleh guru dalam tahap penyebaran ini. Responden 1 adalah guru fisika yang berasal dari SMA Islam, memberikan nilai 3,8 atau dengan kategori sangat baik. Responden 2 berasal dari SMA Majelis Tafsir Al-Quran memberikan nilai 3,8 (sangat baik), Responden 3 berasal dari SMA Muhammadiyah 6 yang menilai 3,6 (sangat baik). Responden 4 adalah guru fisika yang 
berasal dari SMA Warga yang memberikan nilai 3,6 pada modul (sangat baik), dan responden 5 adalah guru fisika yang berasal dari SMA Muhammadiyah 1 yang memberikan penilaian 3,6 (sangat baik) pada modul. Secara keseluruhan pengembangan modul pembelajaran fisika berbasis yang berbasis STM pada materi suhu dan kalor ini mempunyai nilai ratarata seluruhnya 3,68 atau dalam kategori 'sangat baik'. Nilai ini membuktikan bahwa menurut guru fisika di 5 sekolah tersebut, modul fisika berbasis STM yang dikembangkan ini mempunyai kualitas sangat bagus dari segi materi, bahasa dan tampilan/ gambar sehingga sangat layak dipergunakan dalam pembelajaran fisika di SMA/MA. Hal tersebut senada dengan hasil penelitian Sungkono (2003) bahwa pembuatan media pembelajaran yang baik sangat perlu dilakukan demi meningkatkan kualitas pembelajaran.

\section{Kesimpulan dan Rekomendasi}

\section{Kesimpulan}

Modul Fisika telah dikembangkan berbasis sains teknologi masyarakat (STM) untuk meningkatkan motivasi belajar dan kemampuan berpikir kritis siswa. Tahapan STM dalam modul adalah invitasi, pembentukan konsep, aplikasi konsep, pemantapan konsep dan evaluasi.

Modul fisika berbasis STM yang dikembangkan memenuhi kriteria layak pada aspek kelayakan isi dan penyajian, kelayakan bahasa, kelayakan aspek pembelajaran STM, dan kelayakan kegrafikan. Kelayakan modul diperoleh dari nilai rata-rata 3,54 atau dalam kategori 'sangat baik'.

Pembelajaran menggunakan modul fisika berbasis STM efektif untuk meningkatkan motivasi belajar siswa.Peningkatan motivasi belajar diperolehdari nilai gain 0,5 atau dalam kategori sedang.

Pembelajaran menggunakan modul fisika berbasis STM efektif untuk meningkatkan kemampuan berpikir kritis siswa. Peningkatan kemampuan berpikir kritis diperoleh nilai gain 0,39 atau dalam kategori sedang.

Pembelajaran menggunakan modul fisika berbasis STM efektif untuk meningkatkan hasil belajar.Peningkatan hasil belajardiperoleh bahwa 93\% siswa mencapai KKM.

\section{Rekomendasi}

Dalam penggunaan modul pembelajaran berbasis STM perlu diperhatikan beberapa hal diantaranya (1) Dalam penerapan modul fisika berbasis sains teknologi masyarakat (STM) yang dikembangkan perlu persiapan pembelajaran yang baik agar tercapai tujuan pembelajaran. (2) Modul fisika berbasis sains teknologi masyarakat (STM) dapat dijadikan rujukan untuk mengembangkan modul materi fisika yang lebih luas dan berbeda dengan mempertimbangkan proses pembelajaran proses pembelajaran dan kondisi lapangan.

\section{Daftar Pustaka}

Dahar, R, W. (1989). Teori-teori Belajar. Jakarta: Erlangga.

Depdiknas. (2008). Teknik Penyusunan Modul. Jakarta: Depdiknas.

Depdiknas. (2015). Pedoman Umum Ejaan Bhasa Indonesia. Jakarta: Direktorat PLP, Ditjen Dikdasmen, Depdiknas.

Daryanto. (2013). Menyusun Modul Bahan Ajar untuk Persiapan Guru dalam Mengajar. Yogyakarta: Gava Media.

Facione, P.A. (2013). Critical Thinking: What It Is and Why It Counts. California: Measured Reason and The California Academic Press.

Fisher, A. 2009. Berpikir Kritis : Sebuah Pengantar. Jakarta: Erlangga.

Kiong, T.T. et al. (2011). Procedia - Social and Behavioral Sciences, The Development And Evaluation of The Qualitis of Buzan Mid Mapping Module. Malaysia: Universiti Tun Hussein. 
Perdana, F A. (2016). Pengembangan Modul Elektronik Fisika Berbasis Keterampilan Proses Sains untuk Meningkatkan Kemampuan Berpikir Kritis dan Motivasi Belajar Siswa SMA/MA Kelas X Pada Materi Dinamika Partikel. PPS UNS: Surakarta.

Poedjiadi, A. (2010). Sains Teknologi Masyarakat Model Pembelajaran Kontekstual Berbasis Nilai. Bandung : Remaja Rosdakarya.

Putra, S R. (2013). Desain Belajar Mengajar Kreatif Berbasis Sains.Yogyakarta:DIVA Press.

Puspendik. (2013). Laporan Hasil Ujian Nasional Tahun Pelajaran 2012/2013. Jakarta: Kementrian Pendidikan dan Kebudayaan.

Puspendik. (2014). Laporan Hasil Ujian Nasional Tahun Pelajaran 2013/2014. Jakarta: Kementrian Pendidikan dan Kebudayaan.

Rohmadi, Mukhlis. (2011). Pendekatan dengan Pembelajaran CEP (ChemoEntrepreneurship) yang Bervisi SETS (Science, Environment, Technology and Society) guna Meningkatkan Kualitas Pembelajaran. PPS UNS: Surakarta.

Sadia, I W. (2014). Model-Model Pembelajaran Sains Konstruktivisme. Yogyakarta: Graha Ilmu.

Sanjaya, W. (2009).penelitian tindakan kelas.Jakarta: Prenada Media Grup.

Sardiman. (2008). Interaksi dan Motivasi Belajar Mengajar. Jakarta: Raja Grafindo Persada.

Sukiman. (2012). Pengembangan Media Pembelajaran. Yogyakarta: Pedagogia.

Sungkono. (2003). Pengembangan Bahan Ajar. Yogyakarta: FIP UNY.

Sugiyono. (2012). Metode Penelitian Kuantitatif, kualitatif dan $R \& D$. Bandung: Penerbit Alfabeta.

Thiagarajan, Sivasailam, DS, \& Melvyn, S. (1974). Instruction Development for Training Teacher of Exceptional children. Minneapolis: Indian University.

Winkel. (2009). Psikologi Pengajaran. Yogyakarta: Media Abadi. 